\title{
EFFECT OF VARYING RATES OF ORGANIC AMENDMENTS ON POROSITY AND INFILTRATION RATE OF SANDY LOAM SOIL
}

O. E. Essien $\mathrm{PhD}^{1}$

\begin{abstract}
Infiltration rate and porosity of sandy loam soil amended separately with goatyard manure (GYM) and poultry waste at 30,50 and 70 tonnes/hectare each were investigated and the results were statistically analyzed using SPSS ver 17 package. Infiltration rates under GYM amendment and poultry waste amendment showed significant difference $(p \leq 0.01)$, indicating that the variation of infiltration under GYM amendment was superior to the use of poultry waste. Infiltration rates under poultry waste amendment and those of the control soil correlated perfectly $(r=0.99, p \leq 0.01)$. The application of 70t/ha of GYM indicated no superior short-term effect on soil's infiltration rate than its lower amendment rates. The constant infiltration rate of amended soil under 30T/ha of GYM was reduced to $1.60 \mathrm{~cm} / \mathrm{min}$ below the $2.28 \mathrm{~cm} / \mathrm{min}$ for its $G Y M$ counterpart and $1.69 \mathrm{~cm} / \mathrm{min}$ for the control soil; and is recommended for optimum irrigation water conservation in sandy loam soil. The change in porosity was less under GYM amendment than under poultry waste amendment.
\end{abstract}

Key words: Infiltration, organic-amendment rate, porosity, sandyloam, water conservation

\section{INTRODUCTION}

When rainfall or irrigation soaks into the soil, a certain amount of the unfiltered water is temporally retained in the soil pores by capillary action and, if not quickly taken up by roots, gradually percolates downward from the root zone base to the water table at a rate which is equal to the constant infiltration rate or the hydraulic conductivity of the root zone layer (Gupta and Gupta, 2008). The amount of water retained in the topsoil is affected by the amount of organic matter content, the size, shape and arrangement of mineral particles (Gupta and Gupta, 2008). Generally, the more the amount of organic matter the soil contains, the more the water it will be able to absorb depending on the soil texture and structure which are known to be modified by organic amendment (Osunbitan et al, 1998; Ogendengbe and Akinwole, 2000; Ogedengbe and Fashina, 2001; Osunbitan and Adekalu, 2001; Bababe et al, 2003; Gupta and Gupta, 2008). There is also a diminishing effect of the organic waste. The animal manure contains some mineral colloids and these, in soil amendment add colloids to the soil pores, which swell on hydration resulting in the reduction of infiltration rate (Gupta and Gupta 2008). Therefore, the amount of organic waste that is beneficial to infiltration capacity under a given texture, like sandy loam, is of importance to irrigation water supply. Also, when the organic wastes are pulverized, some smithereens or fines are produced. When applied in dry condition of the soil, these fine particles add to the fine particles in the soil surface, but after the rainfall or irrigation application and infiltration starts, these fine particles are moved into and deposited in the voids of the soil. Therefore, apart from the surface cushioning effect from impacting drops of water, the organic wastes affect soil porosity, since the soil pores or filter media are chocked by the deposited fines resulting in the reduction of infiltration capacity during rainfall or irrigation (Gupta and Gupta, 2008). Hence, Brouwer and Powell (1993) claimed that the rate of organic wastes application is of significant consideration as it may be more effective to apply frequent small amount of manure than to apply a lot of manure less frequently. The amount of manure applied is translated into cost of production and if the cost of sustenance of yield - benefiting resource is exorbitant to the small-holder farmers,

1 Dept. of Agri./Food Eng., Uni. of Uyo, P.O. Box 4309, Uniuyo, Uyo, Nigeria. Email: tobessien@yahoo.com. 
who are usually prominent in farming in Nigeria, the willingness to pay diminished and sustained production perished. Thus, how much or what rate of which manure to apply to typical soils like sandy loam soils become a critical issue in amendment soil hydraulic properties and agricultural water supply in developing countries.

\section{OBJECTIVE}

The objective of this research was to investigate the effect of incorporating varying rates of goatyard manure (GYM) and poultry wastes, as soil amendment, on porosity and infiltration capacity of sandy loam soil.

\section{MATERIALS AND METHODS}

The soil sample was tested for texture using sieve analysis and classifying the particle size distribution used textural triangle adapted from Soil Classification Working Group (1991) and FAO soil classification (Schwab et al, 1993).

\section{EXPERIMENTAL SITE PREPARATION}

The sandy loam soil identified above was excavated and conveyed to the experimental site at the College of Agriculture experimental farm. Also, poultry waste and goatyard manure (GYM) of adequate quantity were conveyed to the site. At each of the 3-plot sites, seven square pits, each $50 \mathrm{~cm} \times 50 \mathrm{~cm}$, were dug side by side at $30 \mathrm{~cm}$ strip in-between and to a depth of $30 \mathrm{~cm}$. They received the samples as representing different plot treatments. One hole was back-filled with the loose sandy loam and compacted, the bulk density of the soil under the experimental condition was determined by usual method. The remaining six holes were back-filled with sandy loam soil and compacted to a layer depth of $15 \mathrm{~cm}$. This was repeated in two replicate holes for each rate made at suitable locations in the same field. Then each mixture of the soil sample and the respective animal wastes at different rate was used to fill up the remaining $15 \mathrm{~cm}$ space, using the following rates: Samples of $0.75 \mathrm{~kg}$, $1.25 \mathrm{~kg}$ and $1.75 \mathrm{~kg}$, representing 30,50 and $70 \mathrm{~T} / \mathrm{ha}$, respectively, of GYM. Samples of $0.75 \mathrm{~kg}, 1.25 \mathrm{~kg}$ and $1.75 \mathrm{~kg}$, representing 30,50 and $70 \mathrm{~T} /$ ha respectively of poultry waste. The sand and the animal wastes were pulverized separately to remove clogged waste particles and clod from the soil before spreading out under cover to be air-dried for five days. This action also brought the moisture content to the same starting level in the materials. Thereafter, they were mixed at the above rates and used for the test.

\section{MEASUREMENT OF INFILTRATION RATE}

Seven days after setting up the experiment and allowing the samples to be dried and mixed for the test, the infiltration rates of the various sample plots were measured using double ring cylinder infiltrometer (Reddy, 2006). The $60 \mathrm{~cm}$ and $30 \mathrm{~cm}$ outer and inner rings of the instrument were centered with care on each experimental plot and hammered with a pallet into the soil allowing a depth of $15 \mathrm{~cm}$ above the ground surface and kept as vertical as possible. A metre rule was inserted gently by the inside wall of the inner ring, and the infitrometer was gently filled to the brim with water. The time was recorded with a stop watch and the water drawdown for each time interval was read off the meter rule. This was recorded for the control and the different treatments (the three levels of incorporation for the two types of organic amendment). The data from the replicates were summarized into respective time intervals from which the range of variation of infiltration rates for each time interval was sorted and average accumulated infiltration computed (Michael, 1978)

Graphs of accumulated depth (accumulated infiltration) versus elapsed time were plotted for the six cases, and the constant rate of infiltration was scaled off (Michael, 1978; Raghunath, 2008; Reddy 2006). Descriptive statistics as the mean, standard deviation and covariance were computed. ANOVA and F-ratio statistics were applied to test for significant differences and correlation between infiltration readings of GYM and poultry waste 
treatment of equal amendment rates; and between infiltration rates of the control and respective rates of organic waste treatment.

\section{INCUBATION PERIOD TEST}

Measurements were repeated after seven days to test for incubation period effect. No significant differences in the values were obtained and so were not presented.

\section{MEASUREMENT OF POROSITY}

Similar samples as those used for infiltration test were used also for porosity measurement. A quantity of the dry sample of the control, the GYM -, and the poultry waste amendment soils each was collected into a $250 \mathrm{ml}$-beaker and gently compacted at the levels of $80 \mathrm{ml}$, $160 \mathrm{ml}$ and $250 \mathrm{ml}$. Then water from a measuring cylinder was gently added to the sample in the beaker sample until the intake of water and bubbles from the soil in the beaker soil or soil amendment surface ceased. This indicated that the sample was saturated; the quantity of water at saturation was the difference between the water level before and after usage (or at saturation). Three replications of each measurement were taken and their average value was computed to give; the porosity as:

Porosity $=$ Void Volume $/$ Total Volume of sample

where void volume $=$ the volume of water used in each case representing the volume of pore spaces in the samples.

\section{RESULTS AND DISCUSSIONS}

\section{RESULTS}

The soil texture was sandy loam with $70 \%$ sand, $7 \%$ silt, and $20 \%$ clay together with $3 \%$ organic matter content (omc). The porosity increased with increase in organic amendments (Table 1). Table 2 shows the mean and the constant infiltration rates and standard deviations under different loading rates of GYM and poultry wastes. Tables 3 and 4 show the correlation coefficients and ANOVA statistic for infiltration rates of the GYM amended soil and those of the control. Similarly, Tables 5 and 6 show the correlation coefficients and ANOVA statistics, respectively, for infiltration rates of poultry waste amended soil and those of the control soil while Tables 7 and 8 are those for both GYM and poultry waste amendment. The field bulk density was about $1.54 \mathrm{~kg} / \mathrm{l}$.

Porosity is the volume of the pores or voids as a percentage of the total volume of the sandy loam soil (Bhattacharya and Michael, 2003). It measures the amount of water that each soil can retain in the root zone where it is available to plants. For sandy soils, porosity range is $40-60 \%$ (Michael, 1978). Porosity is texture variant i.e. varies in soils containing varying mass percentages of different sized particles. As such the different mass of organic soil amendment affected it. Some percentage differences in the variation of porosity with rates of organic soil amendment are given in Table 1. Organic amendment caused soil particles rearrangement that made porosity to increase with increasing levels of incorporation. For GYM, soil porosity changed from $15.2 \%$ for $30 \mathrm{~T}$, to $16.3 \%$ for $50 \mathrm{~T}$ up to $17.5 \%$ for $70 \mathrm{~T} / \mathrm{ha}$, giving a mean differential of $1 \%$ increase in porosity per $20 \mathrm{~T} / \mathrm{ha}$, (or $0.0515 \% / \mathrm{t} / \mathrm{ha}$ ) increase in GYM amendment of sandy loam. The increase in porosity with increase in poultry waste amendment rate was higher than those obtained with GYM (Table I). With poultry waste, porosity increased from $20.5 \%$ for $30 \mathrm{~T}$ to 24.1 for $50 \mathrm{~T}$ up to $27 \%$ for $70 \mathrm{~T} / \mathrm{ha}$ giving a mean differential of $3 \%$ per $20 \mathrm{~T}$ (or $0.1625 \% / \mathrm{t} / \mathrm{ha}$ ) change in poultry waste amendment. The porosity change ratio (PCR) between poultry waste and GYM was 2.83 . Thus, porosity increased with increasing rate of amendment, and porosity increase with GYM rate was less in all cases than the poultry waste amendment. 
The porosity of control soil was $12 \%$; therefore the change in porosity with reference to the control level were $3.2 \%, 4.3 \%$ and $5.5 \%$ for $30 \mathrm{~T}$, 50T and $70 \mathrm{~T} / \mathrm{ha}$ GYM respectively while poultry waste leap-jumped to $8.5 \%, 12.1 \%$ and $15.0 \%$ for $30 \mathrm{~T}$, 50T and $70 \mathrm{~T}$ respectively. Hence higher poultry waste tonnage actually made the sandy loam more porous than necessary for any water-saving irrigation on sandy loam soils to be significant. The rate of poultry amendment should, in effect, be less than $30 \mathrm{~T} / \mathrm{ha}$. Unlike the observation in Osunbitan and Adekalu (2001), the incubation period of the two organic amendment in the soil showed no significant $(\mathrm{p} \leq 0.01)$ effect after one week repeated trials and was not reported further. The unexplained component in the correlation of infiltration rate between the control and the amended soils was due to hydration energy loss in the modification of texture by the organic amendment (Gupta and Gupta, 2008).

Table I: Average porosity of sandyloam soil as affected by organic waste amendment

\begin{tabular}{|c|c|c|c|c|c|c|c|}
\hline \multirow[t]{2}{*}{ Organic waste } & \multirow{2}{*}{$\begin{array}{l}\text { Incubation } \\
\text { period (days) }\end{array}$} & \multicolumn{4}{|c|}{ Porosity Change (\%) } & \multirow{2}{*}{$\begin{array}{l}\begin{array}{l}\text { Mean } \\
\text { Change }\end{array} \\
\text { 20T/ha }\end{array}$} & \multirow{2}{*}{$\begin{array}{c}\begin{array}{c}\text { Rate of } \\
\text { Change }\end{array} \\
(\% \mathrm{~T} / \mathrm{ha})\end{array}$} \\
\hline & & 0 & 30 & 50 & 70 & & \\
\hline Goat dung & 7 & 12.0 & 15.2 & 16.3 & 17.5 & $1.15 \%$ & 0.0575 \\
\hline Poultry waste & 7 & 12.0 & 20.5 & 24.1 & 27.0 & $3.25 \%$ & 0.1625 \\
\hline
\end{tabular}

DISCUSSIONS

Incubation period did not show any significant effect on infiltration rates and porosity and as such, was not discussed any further. Least square regression established (Pearson twotailed) correlations between

(i) Infiltration rates of the control and soils amended with (a) GYM and (b) Poultry waste.

(ii) Infiltration rate of GYM and Poultry waste-amended soils.

The GYM-amended soil gave correlation - coefficient ranging from $r=0.90$ for 30T, $r=0.88$ for $50 \mathrm{~T}$ to $r=0.87$ for $70 \mathrm{~T} /$ ha (Table 3 ), all of which were good correlation. Thus $87-90 \%$ of the variations in the infiltration rate between the control soil and the amended soil were due or predictable from the effect of GYM amendment, whereas only $10-13 \%$ of the change (i.e. the error component) in the control could not be predicted by GYM amendment. Thus, the GYM amendment affected the infiltration rate of the amended sandy loam soil significantly $(\leq 0.01$; Table 3$)$.

The regression analysis showed that there was a maximum level of GYM amendment on sandy loam above which a diminishing benefit on infiltration was predicted. The highest correlation coefficient (0.9) for infiltration rate between GYM and control was at 30T/ha of GYM, while at 70T/ha the coefficient was the least $(r=0.87)$ (Table 3$)$ and was significantly $(p<0.01)$ different from the values at 50 and 30T/ha constant infiltration rates of 1.60 , 1.92 and $1.45 \mathrm{~cm} / \mathrm{min}$ for 30,50 and $70 \mathrm{~T} /$ ha, respectively, which are, respectively, $56.4 \%$, $47.6 \%, 6 \%$ and $42 \%$ below the infiltration rate of control soil the advantage of conserving water by using infiltration rate less than the control soil's rate (of $2.5 \mathrm{~cm} / \mathrm{min}$ obtained at a spectrum time of $50 \mathrm{~min}$ (Table 2)) was significantly met by all rates of amendments. The various infiltration rates for the GYM amended soil water - conservation on sandy loam soil are expected to satisfy a wide range of the available rainfall intensity (low or medium) and the designed irrigation application rate suitable to this soil type. Under low rainfall intensity, increased soil porosity was required to store large available water for plant use. Hence, the 70T/ha of GYM amendment, which porosity was significantly different from the control soil( $p \leq 0.01$; Table 4$)$ or which produced medium but high initial infiltration rate $(9.2 \mathrm{~cm} / \mathrm{min}$, Table 2$)$ and had increased porosity $(27 \%)$, facilitated faster water intake and increased root zone water storage with very low outflow (i.e. hydraulic conductivity of $1.45 \mathrm{~cm} / \mathrm{min}$, Table 2). This GYM amendment rate was preferred for the sandy loam soil. 
Table 2: Descriptive statistics for both GYM and Poultry amendments

\begin{tabular}{lccccccc}
\hline Treatment & $\begin{array}{c}\text { Range } \\
\mathrm{cm} / \mathrm{min}\end{array}$ & $\begin{array}{c}\text { Mean } \\
\mathrm{cm} / \mathrm{min}\end{array}$ & $\begin{array}{c}\mathrm{SD} \\
\mathrm{cm} / \mathrm{min}\end{array}$ & $\begin{array}{c}\text { Covariance } \\
(\mathrm{SD} / \text { Mean }) \\
\%\end{array}$ & $\begin{array}{c}\mathrm{K} \\
\mathrm{cm} / \mathrm{min}\end{array}$ & $\begin{array}{c}\text { Spectrum Time } \\
(\mathrm{min})\end{array}$ & $\begin{array}{c}\text { Initial Infiltration rate } \\
(\mathrm{cm} / \mathrm{min})\end{array}$ \\
\hline Control & $1.08-7.60$ & 3.83 & 2.29 & 59.8 & 1.69 & 75 & 7.0 \\
30G & $0.70-5.60$ & 2.67 & 1.70 & 63.7 & 1.60 & 50 & 5.6 \\
50G & $0.79-7.80$ & 3.47 & 2.41 & 69.5 & 1.92 & 50 & 7.8 \\
70G & $0.89-9.20$ & 3.95 & 2.82 & 71.2 & 1.45 & 75 & 9.2 \\
30P & $1.39-13.60$ & 6.03 & 4.13 & 68.5 & 2.28 & 75 & 13.6 \\
50P & $1.26-11.80$ & 5.31 & 3.59 & 67.6 & 2.04 & 75 & 11.8 \\
70P & $1.36-12.60$ & 5.74 & 3.80 & 66.2 & 2.62 & 75 & 12.6 \\
Total & $0.70-13.60$ & 4.43 & 3.16 & 71.3 & & & \\
\hline N/B: G= GYM; P=poultry manure; K=Constant infiltration rate &
\end{tabular}

N/B: G= GYM; P=poultry manure; $\mathrm{K}=$ Constant infiltration rate

Table 3: Correlation coefficients for GYM amendments

\begin{tabular}{ccccc}
\hline Type & Control & 30 & 50 & 70 \\
\hline & 1 & & & \\
Control & $-0.919^{* *}$ & 1 & & \\
30 & $-0.905^{* *}$ & $0.999^{* *}$ & 1 & 1 \\
50 & $-0.883^{* *}$ & $0.995^{* *}$ & $10.997^{* *}$ & 1 \\
70 & $-0.869^{* *}$ & $0.991^{* *}$ & $0.994^{* *}$ & \\
\hline
\end{tabular}

** Significant $\mathrm{P}<0.01$

Table 4: ANOVA statistics for control and GYM amendment

\begin{tabular}{lccccc}
\hline & Sum of Squares & Df & Mean Square & $F$ & Sig. \\
\hline Between Groups & 9.476 & 3 & 3.159 & 0.584 & $0.630 \mathrm{NS}$ \\
Within Groups & 167.596 & 31 & 5.406 & & \\
Total & 177.073 & 34 & & & \\
\hline
\end{tabular}

N/B: NS $\equiv$ not significant at $P<0.01$

The ANOVA statistics for the control and GYM soils (Table 4), however, indicated that the differences in the mean infiltration rates between the control soil and the GYM treatments were not significant $(p \leq 0.01)$. Hence, the mean infiltration rate of the control soil was $3.83 \mathrm{~cm} / \mathrm{min}$, but was $2.67,3.47$ and $3.95 \mathrm{~cm} / \mathrm{min}$ for 30,50 and $70 \mathrm{~T} / \mathrm{ha}$ of the GYM amended soils respectively (Table 2). The value for 30T/ha with standard deviation of $1.70 \mathrm{~cm} /$ ha indicated a more uniform intake rate than others.

The correlation coefficients for the regression between the control soil's infiltration rates and the rates for poultry waste - amendments $(r=0.88$, Table 5$)$ indicated a significant difference ( $p \leq 0.01)$ between the control's and the treatment's values. The correlation coefficients for the different rates of poultry waste amendment and the control were rather or uniquely similar $(r=0.88)$ especially for 50 and $70 \mathrm{~T} /$ ha at $r=0.89$ (Table 5). Thus, the use of $30 \mathrm{~T} /$ ha of poultry waste amendment was most distinctive infiltration rate whereas those of 50 and $70 \mathrm{~T} /$ ha were not different. Thus, the deterministic component in 
the linear relationship between the control soil and the 50 and 70T/ha treatments could be predicted equally (by $88 \%$ ) while the error portion or the unexplained deviations for this association was $11 \%$. It was $12 \%$ for the $30 \mathrm{~T} / \mathrm{ha}$, amendment. The correlation coefficient between $70 \mathrm{~T} / \mathrm{ha}$ of poultry waste and control soil was similar to that between the 50T/ha and control soil and that between their infiltration rates were close or same (Table 5). Hence, the effect of $70 \mathrm{~T} /$ ha poultry amendment was not stronger than the effect of its smaller counterpart; as such the use of $50 \mathrm{~T} /$ ha poultry waste amendment was preferred on sandy loam soil.

Table 5: Correlation coefficients for Poultry amendments

\begin{tabular}{ccccc}
\hline Type & Control & 30 & 50 & 70 \\
\hline Control & 1 & & & \\
30 & $-0.883^{* *}$ & 1 & & \\
50 & $-0.888^{* *}$ & $0.995^{* *}$ & 1 & 1 \\
70 & $-0.889^{* *}$ & $0.996^{* *}$ & $0.999^{* *}$ & \\
\hline
\end{tabular}

** Significant $\mathrm{P}<0.01$

Table 6: ANOVA statistics for control and Poultry amendment

\begin{tabular}{lccccc}
\hline & Sum of Squares & Df & Mean Square & $F$ & Sig. \\
\hline Between Groups & 31.907 & 3 & 10.636 & 0.873 & 0.466 SS \\
Within Groups & 377.741 & 31 & 12.185 & & \\
Total & 409.648 & 34 & & & \\
\hline
\end{tabular}

N/B: SS $\equiv$ very significant

ANOVA statistics (Table 6 ) between infiltration rates of poultry waste amendment and the control soil showed a significant $(p<0.01)$ difference between them, which indicated an increased effect of the poultry waste amendment on sandy loam's infiltration rate (Table 2). The large variation showed:

(i) high error or unexplained deviation of $18 \%$ on their linear regression;

(ii) far higher infiltration rates in amendment soils than in the control soil and

(iii) larger variations in infiltration rate response to different application rates as depicted by the large covariance values (63.7-71.3\% in Table 2 ).

The mean infiltration rates (Table 2 ) were different for the different treatments: $5.31 \pm$ 3.59 and $5.74 \pm 3.80 \mathrm{~cm} / \mathrm{min}$ for 50 and $70 \mathrm{~T} /$ ha poultry waste amendments, respectively. The comparatively large SD indicated the large variation within treatment (as observed in the large within - SS in Table 6). The poultry waste-amended soil fluctuated in its infiltration rate from a hike of $6.03 \mathrm{~cm} / \mathrm{min}$ for $30 \mathrm{~T}$ (the smallest rate) down to $5.31 \mathrm{~cm} / \mathrm{min}$ for $50 \mathrm{~T} / \mathrm{ha}$ and rises again to $5.74 \mathrm{~cm} / \mathrm{min}$ for $70 \mathrm{~T} / \mathrm{ha}$ amendment. This shows that $70 \mathrm{~T} / \mathrm{ha}$ amendment increases water intake nearly as much as 30T/ha does and far more than that of the control soil, while 50T/ha reduced water intake more than the 30T/ha, hence, was a better option. The use of 70T/ha poultry waste with its infiltration rate would be a waste of resources (in quantity of waste and water) on sandy loam compared to the use of $50 \mathrm{~T} / \mathrm{ha}$. Hence, $50 \mathrm{~T} / \mathrm{h}$ a was median or optimum rate for poultry waste amendment.

The treatment-to-treatment correlation coefficients for poultry waste versus GYM amendment (Table 7$)$ were high $(r=0.99)$, thus their corresponding treatment effects were accurately predictable from observations of the effect of each other's treatments. However, their ANOVA statistics (Table 8 ) showed that the infiltration rates of treatments were different from each other and should not be assumed as having similar strength generally. 
Table 7: Correlation coefficients for GYM and Poultry amendments

\begin{tabular}{cccccccc}
\hline Type & Control & $30 \mathrm{G}$ & $50 \mathrm{G}$ & $70 \mathrm{G}$ & $30 \mathrm{P}$ & $50 \mathrm{P}$ & $70 \mathrm{P}$ \\
\hline Control & 1 & & & & & & \\
30G & $0.905^{* *}$ & 1 & & & & & \\
50G & $0.883^{* *}$ & $0.995^{* *}$ & 1 & & & & \\
70G & $0.869^{* *}$ & $0.991^{* *}$ & $0.994^{* *}$ & 1 & & & \\
30P & $0.883^{* *}$ & $0.995^{* *}$ & $0.998^{* *}$ & $0.996^{* *}$ & 1 & & \\
50P & $0.888^{* *}$ & $0.996^{* *}$ & $0.998^{* *}$ & $0.998^{* *}$ & $0.997^{* *}$ & 1 & \\
70P & $0.889^{* *}$ & $0.995^{* *}$ & $0.997^{* *}$ & $0.999^{* *}$ & $0.995^{* *}$ & $0.999^{* *}$ & 1 \\
\hline
\end{tabular}

** Significant

Table 8: ANOVA statistics for both GYM and Poultry amendment

\begin{tabular}{lccccc}
\hline & Sum of Squares & Df & Mean Square & F & Sig. \\
\hline Between Groups & 86.763 & 6 & 14.461 & 1.521 & .188 SS \\
Within Groups & 532.399 & 56 & 9.507 & & \\
Total & 619.162 & 62 & & & \\
\hline
\end{tabular}

N/B: SS $\equiv$ very significant

Different treatment mixes that could be predictable if researched into are $30: 30,30: 50$, $30: 70,50: 70,50: 50,50: 30,70: 70,70: 50$ and 70:30 of opposite amendment. Mixing poultry waste and GYM amendments in the above ratios were not tried on the field but would not expect to change the status more than the value from poultry waste treatment or less than those from GYM treatment. Also, a trial of higher GYM and lower rates of poultry waste treatments on more compact soils like clay series is recommended for further studies.

The mean infiltration rates for GYM treatment fluctuated from 2.7 to $4.0 \mathrm{~cm} / \mathrm{mins}$ for application rate increase from 30 to $70 \mathrm{~T} / \mathrm{ha}$ while it changed from $6.0-5.7 \mathrm{~cm} / \mathrm{mins}$ in a reverse format for 30 to $70 \mathrm{~T} /$ ha of poultry waste amendment. Thus, poultry waste amendment increased infiltration rate 2.3 times the value of 30 T/ha GYM to 1.5 times the value of 50 and 70T/ha GYM. This shows that poultry waste facilitated more infiltration of water per unit ha per tonne of treatment than the GYM. However, both GYM and poultry wastes treatments had significant effect on infiltration rate of sandy loam soil. In terms of water conservation, 50T/ha treatment for both amendments was optimal while 30T/ha GYM gave the least infiltration rate and $30 \mathrm{~T} /$ ha poultry waste gave the highest infiltration rate (Table 2). For water conservation in sandy loam soils, GYM amendment is preferred.

\section{CONCLUSIONS}

Field investigation was conducted on the effects of incorporating different rates of poultry waste and GYM on the porosity and infiltration rates of sandy loam soil at three levels of application, namely: $0.75,1.25$ and $1.75 \mathrm{~kg}$, representing 30,50 and $70 \mathrm{~T} /$ ha respectively. The infiltration rates of the samples were measured after one week using the double ring infiltrometer while the porosity was calculated from direct measurements of total and void volumes. The result showed that 30 and 50T/ha of GYM exhibited lower infiltration rates than the ordinary sandy loam soil while samples of poultry wastes had higher infiltration rates than both the control soil and the GYM. The highest mean rate of infiltration $(6.03 \mathrm{~cm} / \mathrm{min})$ was exhibited by the lowest rate of application of poultry waste $(30 \mathrm{~T} / \mathrm{ha})$, while it was the reverse situation for GYM amendment, $(2.67 \mathrm{~cm} / \mathrm{min}$ for $30 \mathrm{~T} / \mathrm{ha})$. Porosity was also highest with the highest level of poultry waste application. From this investigation GYM amendment is recommended to check excessive infiltration while both poultry waste and GYM can be used for the improvement of porosity of compacted sandy loam soil. 


\section{REFERENCES}

Bababe, B., M. M. K. Chetima and G. Jang, 2003. Effect of applying organic amendments on the infiltration parameters of a sandy loam soil. Proc. Fourth International Conference and $25^{\text {th }}$ AGM of Nigerian Institution of Agricultural Engineers, Volume 25, pp. $109-119$.

Bhattacharya, A. K. and A. M. Michael, 2003. Land Drainage: Principles, Methods and Applications. New Delhi: Konark Publishers Pvt. Ltd.

Brouwer, J. and J. M. Powell, 1993. Some aspects of nutrients cycling in a manure application experiment in Nigeria. In: J. Boardman, I. D. L. Fostar and J. A. Dearing (eds.), Soil Erosion on Agricultural Land. John Wiley, Chichester, pp. 331 - 338.

Gupta, B. L. and A. Gupta, 2008. Water Resources Systems and Management. Delhi - 110006: Standard Publishers Distributors. Available at www.standardpublishers.com.

Michael, A. M., 1978. Irrigation: Theory and Practice. New Delhi: Vikas Publishing House Pvt. Ltd., pp. 462-582.

Ogedengbe, K. and A. D. Akinwole, 2000. Evaluation of goat and poultry manure as soil amendment for okra production on sandy loam soil in Kaduna State of Nigeria. Proc. of First International Conference and Annual General Meeting of Nigerian Institution of Agricultural Engineers, Vol. 22, pp. 140- 143.

Ogedengbe, K. and A. O. Fashina, 2001. Waste management of cattle and poultry manures in vegetables production in a sandy loam. Proc. of Nigerian Institution of Agricultural Engineers, September 10-14, Enugu, Vol. 23, pp. 213.

Osunbitan, J. A. and K. O. Adekalu, 2001. The effect of incorporating organic wastes on the porosity of two South Western Nigeria soils. Proc NIAE: September 10-14, Enugu, Volume 23, pp.145-150.

Osunbitan, J. A., O. B. Aluko and K. O. Adekalu,1998. Effect of incorporating organic waste on the porosity of sandy clay loam. Proc. of Nigerian Society of Agricultural Engineers, $9^{\text {th }}-11^{\text {th }}$ September Volume 20, pp.174 - 176.

Raghunath, H. M., 2008. Hydrology Principles, Analysis, Design (second edition). New Delhi: New Age International Publishers. Available at www.newagepublishers.com.

Reddy, P. J. R., 2006. Introduction to Hydrology (in MKS and SI units). New Delhi: Laxmi Publications.

Schwab, G. O., D. D. Fangmeier, W. J. Elliot and R. K. Frevert, 1993. Soil and Water Conservation Engineering (fourth edition). New York: John Wiley and Sons, Inc.

Soil Classification Working Group, 1991. Soil classification: a taxonomic system for South Africa. Soil and Irrigation Research Institute, Department of Agricultural Development. Pretoria, South Africa. 